\title{
DNA-Binding and Anticancer Activity of Binuclear Gold(I) Alkynyl Complexes with a Phenanthrenyl Bridging Ligand
}

\author{
Mona S. Alsaeedi ${ }^{1,2}$, Bandar A. Babgi ${ }^{1,3, *}$, Mostafa A. Hussien ${ }^{1}$, Magda H. Abdellattif ${ }^{2}{ }^{\circledR}$ \\ and Mark G. Humphrey 4 \\ 1 Department of Chemistry, Faculty of Science, King Abdulaziz University, P.O. Box 80203 Jeddah 21589, \\ Saudi Arabia; m.s.alsaeedi@outlook.com (M.S.A.); mostafa_aly2@yahoo.com (M.A.H.) \\ 2 Department of Chemistry, Faculty of Science, Taif University, Al-Haweiah, P.O. Box 888, Taif 21974, \\ Saudi Arabia; magdah11uk@hotmail.com \\ 3 Department of Chemistry, College of Science and Arts, King Abdulaziz University, \\ P.O. Box 344 Rabigh 21911, Saudi Arabia \\ 4 Research School of Chemistry, Australian National University, Canberra, ACT 2601, Australia; \\ mark.humphrey@anu.edu.au \\ * Correspondence: bbabgi@kau.edu.sa; Tel.: +966-555563702
}

Academic Editor: Kristof Van Hecke

Received: 10 January 2020; Accepted: 21 February 2020; Published: 25 February 2020

\begin{abstract}
Diethynyl-9,10-diethoxyphenanthrene (4) was synthesized from phenanthrene and employed in the synthesis of the binuclear gold(I) alkynyl complexes $\left(\mathrm{R}_{3} \mathrm{P}\right) \mathrm{Au}\left(\mathrm{C} \equiv \mathrm{C}-3-\left[\mathrm{C}_{14} \mathrm{H}_{6}-9\right.\right.$, 10-diethoxy]-6-C $\equiv \mathrm{C}) \mathrm{Au}\left(\mathrm{PR}_{3}\right)(\mathrm{R}=\mathrm{Ph}(\mathbf{5 a}), \mathrm{Cy}(\mathbf{5 b}))$. The diyne 4 and complexes $5 \mathbf{a}$ and $\mathbf{5 b}$ were characterized by NMR spectroscopy, mass spectrometry, and elemental analysis. UV-Vis spectroscopy studies of the metal complexes and precursor diyne show strong $\pi \rightarrow \pi^{*}$ transitions in the near UV region that red shift by ca. $50 \mathrm{~nm}$ upon coordination at the gold centers. The emission spectrum of 4 shows an intense fluorescence band centered at $420 \mathrm{~nm}$ which red shifts, slightly upon coordination of $\mathbf{4}$ to gold. Binding studies of $\mathbf{4}, \mathbf{5 a}$, and $\mathbf{5 b}$ against calf thymus DNA were carried out, revealing that $4, \mathbf{5 a}$, and $\mathbf{5 b}$ have $\geq 40 \%$ stronger binding affinities than the commonly used intercalating agent ethidium bromide. The molecular docking scores of $\mathbf{4}, \mathbf{5} \mathbf{a}$, and $\mathbf{5} \mathbf{b}$ with B-DNA suggest a similar trend in behavior to that observed in the DNA-binding study. Unlike the ligand 4, promising anticancer properties for $\mathbf{5 a}$ and $\mathbf{5 b}$ were observed against several cell lines; the DNA binding capability of the precursor alkyne was maintained, and its anticancer efficacy enhanced by the gold centers. Such phenanthrenyl complexes could be promising candidates in certain biological applications because the two components (phenanthrenyl bridge and metal centers) can be altered independently to improve the targeting of the complex, as well as the biological and physicochemical properties.
\end{abstract}

Keywords: gold(I) alkynyls; phenanthrene; DNA-binding; anticancer activity

\section{Introduction}

Pioneering studies in supramolecular chemistry by Cram, Lehn, and Pedersen directed attention to "host-guest" systems [1-5]. One particularly interesting application of this concept is the design of new drugs displaying interactions (covalent or noncovalent) with host biological systems such as DNA, enzymes, and proteins [6]. Non-classical (noncovalent) DNA binding modes such as intercalation or groove-binding play a vital role in the pursuit of more efficient and more target-specific drugs displaying fewer side effects [7]. In the field of bioinorganic chemistry, the DNA-binding of platinum [8], ruthenium [9,10], copper [11,12], palladium [13], and gold [14] complexes has been extensively studied due to the array of readily available ligands for coordination, together with the different geometries, 
coordination numbers, redox potentials, kinetic and thermodynamic characteristics of the resultant complexes. Ligands such as the $\pi$-delocalized planar polypyridyls (e.g., diphenylphenazine) have afforded moderate-to-strong DNA-intercalating complexes [15,16]. Modified acetylacetonato [17], amine [18,19], arene [20-22], and Schiff base [23,24] ligands have also been used in DNA-binding complex construction. In the pursuit of efficient DNA binders, one well-known strategy is to use a polycyclic aromatic fragment in the ligand that has been designed to form $\pi-\pi$ interactions with specific units in the DNA $[25,26]$. One example employing this approach is the rhodium complex $\left[\mathrm{Rh}\right.$ (trien- $\left.\mathrm{Me}_{2}\right)$ (phenanthrene-9,10-diimine) $]^{3+}$ (trien- $\mathrm{Me}_{2}=2 R, 9 R$-diamino-4,7-diazadecane) which was specifically designed to intercalate into the $5^{\prime}$-TGCA-3' sequences in the major groove of DNA; in addition to the water-mediated hydrogen bonds of the trien- $\mathrm{Me}_{2}$ ligand, the phenanthrene contributes to the DNA binding through $\pi$-stacking forces [27]. More recently, attention has been paid to the use of these complexes as chemotherapeutic agents for cancer [28], DNA conformation probes [29], and DNA cleavage agents [30]. Cisplatin is one of the most important chemotherapeutic agents for the treatment of certain types of cancers. Its mechanism of action is believed to involve interference with DNA replication, interference with transcription, and modification of chromatin [31-33]. However, in addition to its solubility problems, the non-target-specific action of the drug and its inactivation in biological environments by reducing agents such as metallothioneins, cisplatin causes many side-effects which limit the doses that can be employed [32,34,35]. As a result of these well-documented problems, extensive research is ongoing to develop new classes of metal complexes that can interfere with cancer cell machinery through interactions with DNA, and this has resulted in an increased interest in developing gold-based anticancer drugs. In this context, gold(I) complexes of the type $\mathrm{Au}\left(\mathrm{C} \equiv \mathrm{CR}^{\prime}\right)\left(\mathrm{PR}_{3}\right)$ have been reported to exhibit very strong inhibition of the enzyme thioredoxin reductase (TrxR) and show high antiproliferative activity in tumor cells [36-38]. The R and $\mathrm{R}^{\prime}$ groups in the gold(I) complexes play a significant role in the lipophilicity, stability, and binding affinity and, hence, their mechanism of action [39,40]. Gold(I) alkynyls with $\mathrm{P}\left(\mathrm{NMe}_{2}\right)_{3}$ ligands have been reported to have a higher anticancer activity against Caco-2 cells than cisplatin; the complexes feature a favorable combination of hydrophilicity and lipophilicity and good stability under physiological conditions [41]. A range of gold phosphine complexes with alkynyl ligands end-functionalized with flavone-derived moieties have shown remarkable cytotoxicity. They function through two mechanisms, triggering apoptotic cell death via the intrinsic pathway and altering cell cycle progression [42].

In the current work, a phenanthrene-based ligand functionalized with terminal alkynyl groups has been constructed, with the goal of obtaining strongly intercalating DNA binders facilitated by the phenanthrene polycyclic aromatic system. In principal, the terminal alkynes can be $\sigma$-bonded to a range of metal centers to obtain the corresponding alkynyl complexes; gold(I) phosphine centers were chosen in the present work to generate complexes with potential anticancer activities. The binding constants of the new compounds and complexes were compared to that of the structurally closely related intercalating agent ethidium bromide, and the cytotoxicity of the compounds were assessed against several cancer cell lines and compared to that of cisplatin.

\section{Results and Discussion}

\subsection{Synthesis and Characterization}

The present studies target phenanthrenyl-based alkynyls and their binuclear gold alkynyl complexes. 3,6-Diethynyl-9,10-diethoxyphenanthrene was identified as the key building block. To synthesize this, phenanthrene was subjected to oxidation by a mixture of potassium dichromate and sulfuric acid, leading to the formation of phenanthrene-9,10-dione in a good yield. Then the dione was reduced and, subsequently, treated with ethyl bromide under basic conditions, affording 9,10-diethoxyphenanthrene (1). Treating 1 with excess bromine while following the reaction with TLC gave 3,6-dibromo-9,10-diethoxyphenanthrene (2) in moderate yields. It is important to highlight that prolonged stirring of the mixture leads to the cleavage of the $\mathrm{C}-\mathrm{O}$ bond and 
the formation of 3,6-dibromophenanthrene-9,10-dione (Figures S28 and S29). Compound 2 was coupled with two equivalents of ethynyltrimethylsilane, using $\mathrm{PdCl}_{2}\left(\mathrm{PPh}_{3}\right)_{2}$ and $\mathrm{CuI}$ as catalysts in triethylamine, to give 3 . The silyl-containing compound 3 was desilylated on treatment with $\mathrm{K}_{2} \mathrm{CO}_{3}$, to produce 3,6-diethynyl-9,10-diethoxyphenanthrene (4) (Scheme 1). Rather than proceed via bromination, iodination of $\mathbf{1}$ was tried using several procedures; however, most of these attempts produced 3,6-diiodophenanthrenedione as the main product, together with many inseparable side-products [43-45]. The organic precursors were characterized by a combination of elemental analyses, mass spectrometry and IR, and ${ }^{1} \mathrm{H}$ and ${ }^{13} \mathrm{C}-\mathrm{NMR}$ spectroscopies. Finally, the gold(I) alkynyl complexes $\mathbf{5} \mathbf{a}$ and $\mathbf{5 b}$ were obtained successfully by reacting two molar equivalents of the metal-containing precursor with ligand 4, using modified literature procedures (Scheme 2) [46]. The potassium tert-butoxide helps to remove chloride from the gold center, precipitating $\mathrm{KCl}$, and freeing a coordination site for the alkynyl ligand. The formation of the gold alkynyl complexes is a straightforward reaction due to the preference of gold(I) complexes to form linear or trigonal planar complexes (copper(I) and silver(I) have more complicated and less predictable chemistry with acetylenes) [47]. The reaction can be followed easily by ${ }^{31} \mathrm{P}-\mathrm{NMR}$ because the $\mathrm{PR}_{3}$ signal (singlet) is down-field shifted when the chlorido ligand is substituted by the alkynyl ligand [48]. The ${ }^{31} \mathrm{P}-\mathrm{NMR}$ spectrum of the gold alkynyl complex 5a shows one singlet around $42 \mathrm{ppm}$ [49], whereas that of $5 \mathbf{b}$ shows a singlet around $56 \mathrm{ppm}$ [50]. IR spectra display bands between 2090 and $2100 \mathrm{~cm}^{-1}$ corresponding to the stretching frequencies of the gold-bound $\mathrm{C} \equiv \mathrm{C}$ unit. High resolution mass spectra show the molecular ion of the complexes. Other routine analytical techniques were used to verify the identities of the metal complexes, and the resultant data are listed in the experimental section.

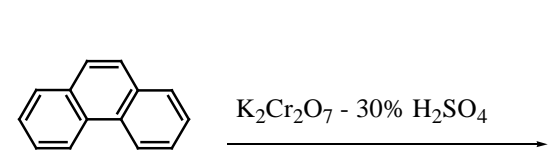

$\Delta$

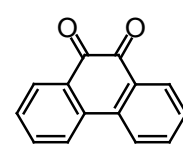

(I) $\mathrm{Na}_{2} \mathrm{~S}_{2} \mathrm{O}_{4}-\mathrm{THF} / \mathrm{H}_{2} \mathrm{O}$

(II) $\mathrm{KOH}-\mathrm{Bu}_{4}{ }^{\mathrm{n}} \mathrm{NBr}-\mathrm{EtBr}$

$\Delta$

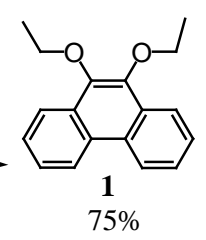

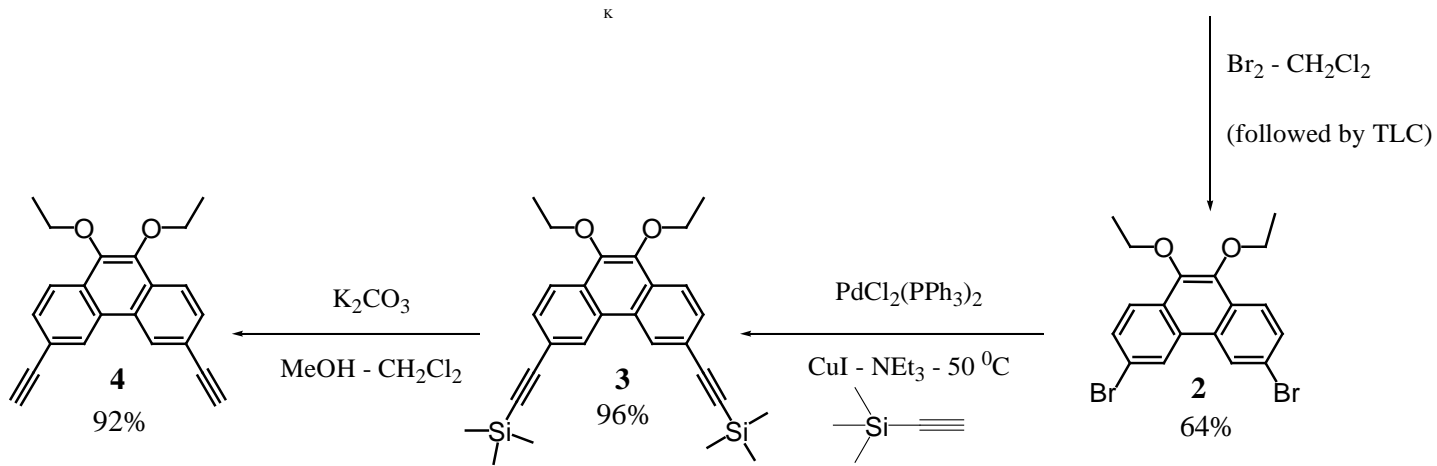

Scheme 1. Synthesis of 3,6-diethynyl-9,10-diethoxyphenanthrene (4).
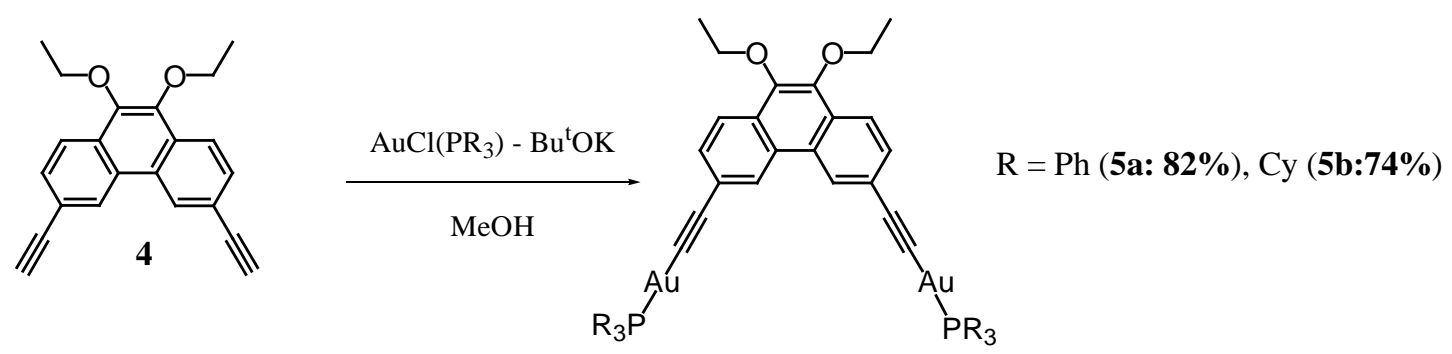

Scheme 2. Synthesis of complexes $5 \mathbf{a}$ and $\mathbf{5 b}$. 


\subsection{Absorption and Emission Spectra}

The phenanthrene polycyclic aromatic system is known for its intense absorption bands in the near UV region, as well as its characteristic fluorescence. In this work, the incorporation of gold alkynyl complexes in such a system affords the opportunity to assess the impact of this modification on the photophysical properties. Absorption maxima and intensities obtained from the electronic spectra of $\mathbf{4}$ and the gold complexes $\mathbf{5 a}$ and $\mathbf{5 b}$ are overlaid in Figure 1 . The electronic absorption spectrum of the free ligand 4 displays three bands at $316 \mathrm{~nm}, 323 \mathrm{~nm}$, and $338 \mathrm{~nm}$. The introduction of $\mathrm{Au}\left(\mathrm{PR}_{3}\right)$ fragments at the ligand 4 affords the binuclear gold(I) complexes $\mathbf{5 a}$ and $\mathbf{5 b}$ and leads to a weak red shift in the three absorption bands of the ligand $(327 \mathrm{~nm}, 342 \mathrm{~nm}$, and $362 \mathrm{~nm}$ ) (Figure 1). The red shifts observed on proceeding to the metal complexes are consistent with a decrease in the energy gap between the HOMO and the LUMO. The free ligand 4 shows an intense broad emission in the near ultraviolet-violet domain upon excitation at $320 \mathrm{~nm}$. Introducing $\mathrm{Au}\left(\mathrm{PPh}_{3}\right)$ or $\mathrm{Au}\left(\mathrm{PC} y_{3}\right)$ fragments to $\mathbf{4}$ on proceeding to $\mathbf{5 a}$ and $\mathbf{5 b}$ causes a red shift in the emission bands with almost the same intensities to those of the ligand (both measured at the same concentration) upon excitation at $350 \mathrm{~nm}$ (Figure 2).

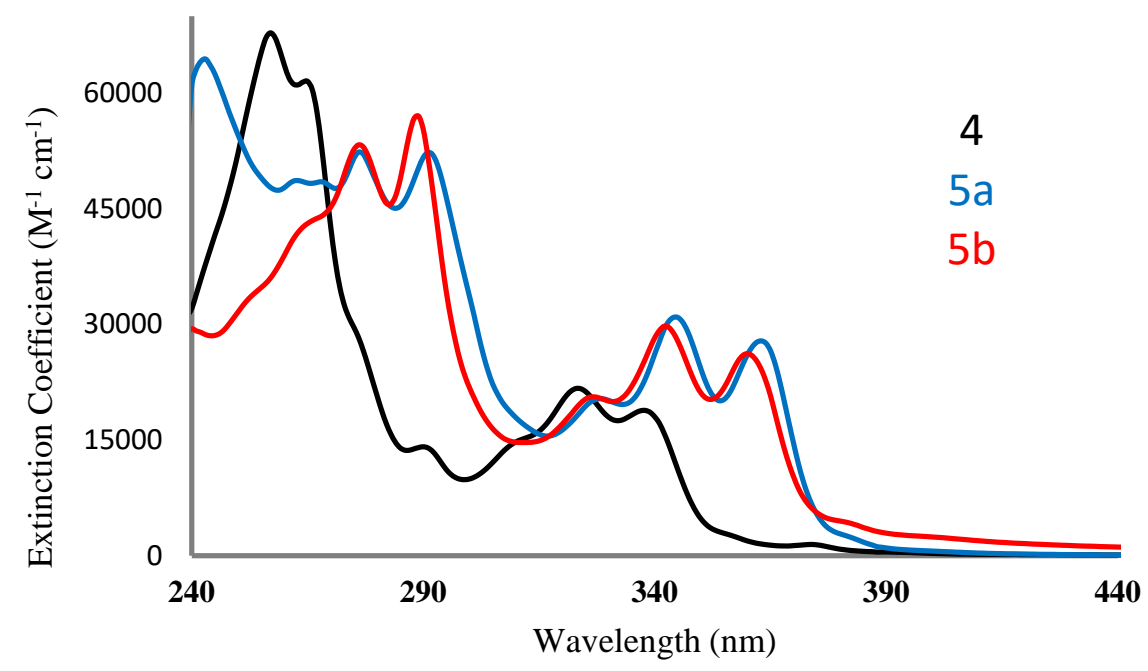

Figure 1. Absorption spectra of $\mathbf{4}, \mathbf{5 a}$, and $\mathbf{5 b}$ in $\mathrm{CHCl}_{3}$.

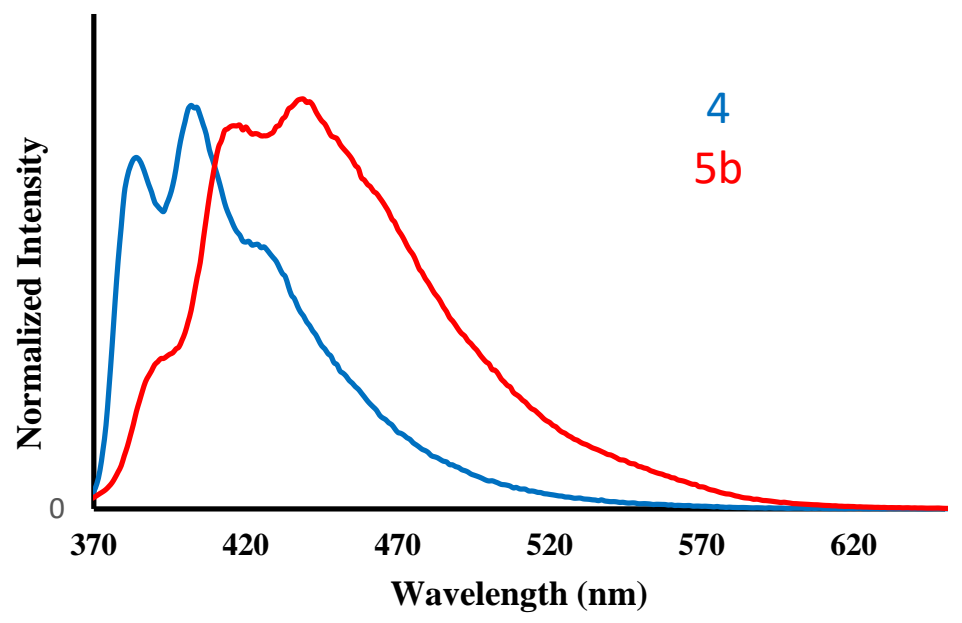

Figure 2. Overlaid normalized emission spectra of 4 and $5 b$. 


\subsection{DNA-Binding Studies}

The DNA-binding studies were performed by titrating the compounds with DNA and monitoring the changes spectroscopically. Ethidium bromide was used as a benchmark; it is a fluorophore that binds to DNA by intercalation, and therefore it is used as a fluorescent tag in molecular biology. The binding affinities of the ligand, two gold complexes, and ethidium bromide are summarized in Table 1.

Table 1. DNA binding affinities toward ct-DNA determined via different methods.

\begin{tabular}{cc}
\hline Compound & $\mathbf{K}_{\mathbf{b}}$ (DNA Binding Constant) \\
\hline Ethidium Bromide & $5.00 \times 10^{5}$ \\
$\mathbf{4}$ & $7.40 \times 10^{5}$ \\
$\mathbf{5 a}$ & $8.71 \times 10^{5}$ \\
$\mathbf{5 b}$ & $7.00 \times 10^{5}$ \\
\hline
\end{tabular}

The $K_{b}$ values of the compounds show that 3,6-diethynyl-9,10-diethoxyphenanthrene (4) has better binding affinity toward ct-DNA than ethidium bromide. Unfavorable steric interactions of the phenyl group of ethidium bromide probably limit its intercalation in DNA, although the amino groups can also contribute via acid-base interactions or hydrogen bonding. In our system, the two flexible ethoxy groups reduce the possibility of steric hindrance as compared with the phenyl group in ethidium bromide, while the acetylene groups can participate in donor-acceptor interactions. Replacing the acidic hydrogen of 4 with gold(I) phosphine metal centers leads to a slight enhancement in the binding constant in the case of the complex with the triphenylphosphine co-ligand, while a slight decrease is observed upon the introduction of the tricyclohexylphosphine co-ligand. $\mathrm{PPh}_{3}$ has a smaller cone angle than $\mathrm{PCy}_{3}$, leading to better interactions of the phenanthrenyl with the ct-DNA (Table 1). The emission behaviors of $\mathbf{4}, \mathbf{5 a}$, and $\mathbf{5 b}$ were monitored as they were titrated with a buffer solution of DNA; the three compounds exhibited a notable enhancement in their emission on increasing the concentration of the ct-DNA, which suggests that these compounds are successfully intercalating, isolating, and rigidifying them, and thereby decreasing deactivation pathways (Figure 3).

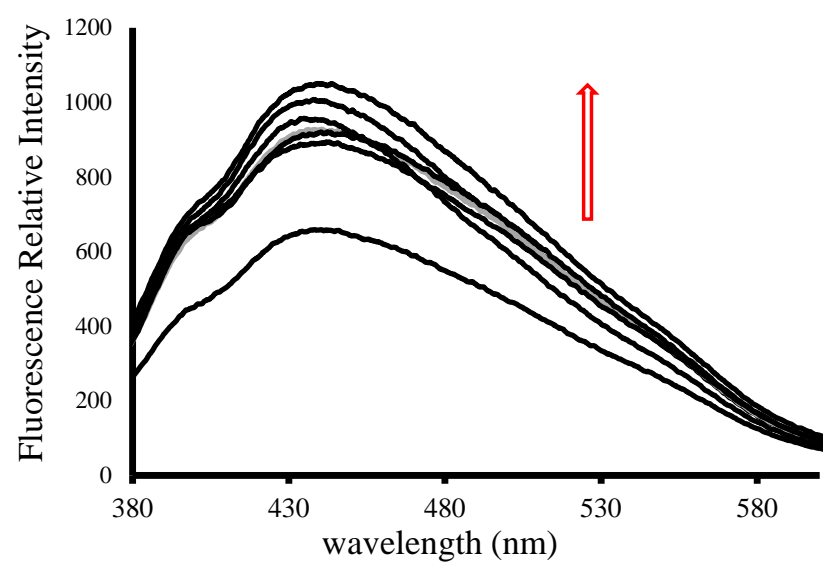

Figure 3. An enhancement in the fluorescence of 5a upon increasing the concentration of ct-DNA.

\subsection{Molecular Docking Studies}

Ethidium bromide, the phenanthrene-based ligand 4 , and gold complexes $5 \mathbf{a}$ and $5 \mathbf{b}$ were computationally docked with B-DNA to rationalize the trends from the binding constant values. The data obtained are summarized in Table 2, revealing that all compounds, in this study, target the same location on the B-DNA. In general, the docking scores and pi-pi interactions increased following the order: $\mathbf{5 b}$, ethidium bromide, $\mathbf{4}$, and then $\mathbf{5 a}$. According to the docking studies, the ethidium 
bromide establishes pi-pi interactions with deoxyadenosine (DA) and thymidine (DT) nucleotides on strand B (Figure 4 and Table 2). In the case of 4 , it is able to establish interactions with two strands of the ct-DNA, i.e., donor-acceptor interactions are observed on the acetylene with deoxyadenosine (DA) nucleotides, in addition to pi-pi interactions with several deoxyadenosine (DA) and thymidine (DT) nucleotides (Figure 4 and Table 2). In contrast, the gold complexes establish pi-pi interactions with DA and DT on strand B in the major groove (Figure 4 and Table 2). The docking scores follow a similar trend to the $\mathrm{K}_{\mathrm{b}}$ values. Examining the $\pi-\pi$ distances (between the interacting B-DNA on one side and ethidium bromide, $\mathbf{4}, \mathbf{5 a}$, and $\mathbf{5 b}$ on the other side), we note that complex $\mathbf{5 a}$ has the shortest distance (3.09 ̊́), which supports the experimental binding affinity values.

Table 2. Docking study results for $4,5 a$, and $5 b$.

\begin{tabular}{|c|c|c|c|c|c|}
\hline Compound & Docking Score & Ligand & Receptor & Interaction & Distance \\
\hline \multirow{2}{*}{$\begin{array}{l}\text { Ethidium } \\
\text { Bromide }\end{array}$} & \multirow{2}{*}{-4.6372} & Phenanthridine & 5-ring DA 18 (B) & pi-pi & 3.80 \\
\hline & & Phenanthridine & 6-ring DT 19 (B) & pi-pi & 3.83 \\
\hline \multirow{6}{*}{4} & \multirow{6}{*}{-5.1630} & $\mathrm{C} \equiv \mathrm{C}$ & OP2 DA 17 (B) & H-donor & 3.11 \\
\hline & & Phenanthrene & 6-ring DA 17 (B) & pi-pi & 3.87 \\
\hline & & Phenanthrene & 5-ring DA 17 (B) & pi-pi & 3.56 \\
\hline & & Phenanthrene & 6-ring DT 19 (B) & pi-pi & 3.36 \\
\hline & & Phenanthrene & 6-ring DA 18 (B) & pi-pi & 3.21 \\
\hline & & Phenanthrene & 6-ring DA 6 (A) & pi-pi & 3.95 \\
\hline \multirow{7}{*}{$5 a$} & \multirow{7}{*}{-5.4070} & Phenanthrene & 5-ring DA 17 (B) & pi-pi & 3.28 \\
\hline & & Phenanthrene & 5-ring DA 18 (B) & pi-pi & 3.77 \\
\hline & & Phenanthrene & 5-ring DA 17 (B) & $\mathrm{pi}-\mathrm{p}$ & 3.65 \\
\hline & & Phenanthrene & 6-ring DA 18 (B) & pi-pi & 3.63 \\
\hline & & Phenanthrene & 6-ring DA 17 (B) & pi-pi & 3.09 \\
\hline & & Phenanthrene & 5-ring DA 17 (B) & pi-pi & 3.75 \\
\hline & & Phenanthrene & 6-ring DT 19 (B) & pi-pi & 3.99 \\
\hline \multirow{2}{*}{$5 b$} & \multirow{2}{*}{-4.1090} & Phenanthrene & 5-ring DA 18 (B) & pi-pi & 3.41 \\
\hline & & Phenanthrene & 6-ring DT 19 (B) & pi-pi & 3.50 \\
\hline
\end{tabular}

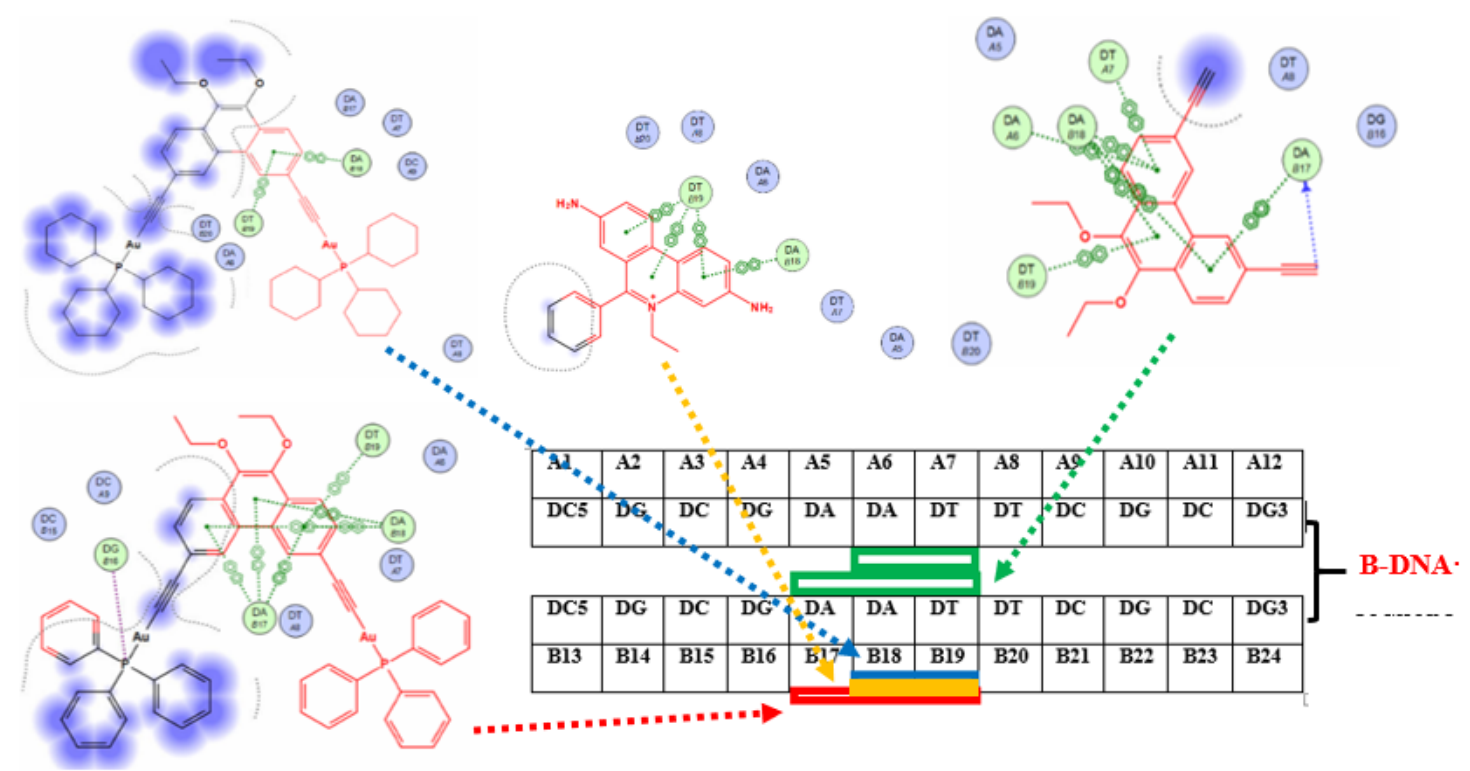

Figure 4. Illustration of the ct-DNA interactions of ethidium bromide, $\mathbf{4}, \mathbf{5 a}$, and $\mathbf{5 b}$ and their targeted nucleotides. 


\subsection{Anticancer Studies}

Compounds 3,4 , and gold complexes $\mathbf{5 a}$ and $\mathbf{5 b}$ were examined against four cancer cell lines to evaluate their anticancer properties, the results being listed in Table 3. Initial inspection of the results revealed that the organic compounds have no significant anticancer activity while the gold complexes have remarkable cytotoxicity against the four cell lines. The cytotoxicity of cisplatin against MCF-7 and PC-3 cell lines has been used to benchmark the anticancer activity of the gold complexes. We conclude that the gold complexes have comparable or better activities. Several binuclear gold(I) alkynyl compounds have been reported recently with good antitumor activities [36,51], but the drawback to their applications in biological assays is their solubility problems (high lipophilic character). In this regard, the phenanthrene unit in the present system can be altered at Positions 9 and 10, allowing greater control of the lipophilic character of the complexes, and thereby potentially circumventing the solubility concerns.

Table 3. Anticancer activities of selected compounds in DMSO solutions.

\begin{tabular}{ccccc}
\hline \multirow{2}{*}{ Complex } & \multicolumn{4}{c}{ IC50 \pm SD $(\boldsymbol{\mu M})$} \\
\cline { 2 - 5 } & MCF-7 & HEPG-2 & PC-3 & MOLT-4 \\
\hline $\mathbf{3}$ & $193.37 \pm 0.20$ & $164.56 \pm 0.20$ & $149.28 \pm 0.22$ & $177.87 \pm 0.16$ \\
$\mathbf{4}$ & $283.48 \pm 0.13$ & $245.78 \pm 0.15$ & $227.63 \pm 0.06$ & $269.02 \pm 0.10$ \\
$\mathbf{5 a}$ & $22.58 \pm 0.03$ & $26.01 \pm 0.03$ & $27.46 \pm 0.01$ & $25.91 \pm 0.03$ \\
$\mathbf{5 b}$ & $18.63 \pm 0.03$ & $27.94 \pm 0.03$ & $27.31 \pm 0.01$ & $20.28 \pm 0.03$ \\
Cisplatin & $16.00 \pm 0.06$ & - & $39.99 \pm 0.05$ & - \\
\hline
\end{tabular}

\section{Materials and Methods}

\subsection{Materials}

All reactions were carried out using standard Schlenk techniques, under a nitrogen atmosphere. $\mathrm{NEt}_{3}$ was distilled over $\mathrm{KOH}$ according to standard procedures; other solvents were obtained from Sigma-Aldrich (St. Louis, MO, USA) and were used as received. The term "petrol" refers to a fraction of petroleum ether with a boiling range of $40-60^{\circ} \mathrm{C}$. Experiments containing moisture sensitive compounds were performed using anhydrous solvents and oven-dried $\left(120^{\circ} \mathrm{C}\right)$ glassware. Chromatography was carried out on silica gel 60 particle sizes 0.063 to $0.200 \mathrm{~mm}$ (70 to 230 mesh ASTM) or basic ungraded alumina. Copper iodide, trans-bis(triphenylphosphine)palladium(II) dichloride, $p$-bromoiodobenzene, tetra- $n$-butylammonium bromide (TBABr), potassium tert-butoxide, trimethylsilylacetylene (TMSA), bromine, and bromoethane were purchased commercially and used as received. The following compounds were prepared according to literature procedures: phenanthrene-9,10-dione [52], $\mathrm{AuCl}\left(\mathrm{PPh}_{3}\right)$ [53], and $\mathrm{AuCl}\left(\mathrm{PCy}_{3}\right)$ [54].

\subsection{Methods and Instrumentation}

High-resolution electrospray ionization (ESI) mass spectra were recorded at the Australian National University, using a Bruker Apex 4.7 FTICR-MS instrument (Billerica, MA, USA); all mass spectrometry peaks are reported as $m / z$ (assignment). Elemental analyses were obtained at King Abdulaziz University. Infrared (IR) spectra were recorded using solid samples on a PerkinElmer Spectrum 100 instrument (Waltham, MA, USA); peaks are reported in $\mathrm{cm}^{-1}$. UV-Vis spectra were recorded in $1 \mathrm{~cm}$ quartz cells on a MultiSpec-1501 UV-VIS spectrophotometer (Kyoto, Japan) as chloroform solutions; bands are reported in the form wavelength $(\mathrm{nm})$ (extinction coefficient, $10^{4} \mathrm{M}^{-1} \mathrm{~cm}^{-1}$ ). UV-Vis emission spectra were recorded for nitrogen-purged chloroform solutions in $1 \mathrm{~cm}$ quartz cells using a PerkinElmer LS-55 fluorescence spectrometer; bands are reported in the form wavelength (nm). ${ }^{1} \mathrm{H}(850 \mathrm{MHz})$, ${ }^{31} \mathrm{P}(344 \mathrm{MHz})$, and ${ }^{13} \mathrm{C}(214 \mathrm{MHz}) \mathrm{NMR}$ spectra were obtained from $\mathrm{CDCl}_{3}$ solutions using a Bruker Avance $850 \mathrm{MHz}$ spectrometer. The spectra are referenced to residual chloroform $\left(7.26,{ }^{1} \mathrm{H}\right), \mathrm{CDCl}_{3}$ $\left(77.0,{ }^{13} \mathrm{C}\right)$, or external $\mathrm{H}_{3} \mathrm{PO}_{4}\left(0.0 \mathrm{ppm},{ }^{31} \mathrm{P}\right)$; atom labeling follows the numbering in Figure 5. 


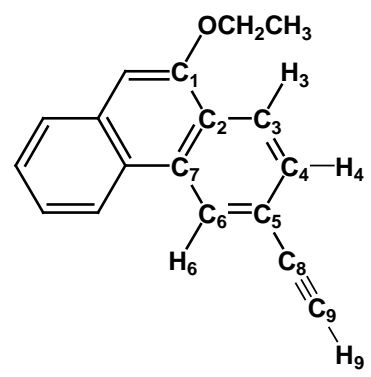

Figure 5. Numbering Scheme for NMR Spectral Assignments.

\subsection{Synthesis and Characterization}

Synthesis of 9,10-diethoxyphenanthrene (1). Tetra(n-butyl)ammonium bromide (1.032 $\mathrm{g}, 3.20 \mathrm{mmol})$ and $\mathrm{Na}_{2} \mathrm{~S}_{2} \mathrm{O}_{4}(6.055 \mathrm{~g}, 31.81 \mathrm{mmol})$ were added to a solution of phenanthrene-9,10-dione (2.00 $\mathrm{g}$, $9.60 \mathrm{mmol})$ in THF $(60 \mathrm{~mL})$ and $\mathrm{H}_{2} \mathrm{O}(60 \mathrm{~mL})$. After $5 \mathrm{~min}, \mathrm{KOH}(3.563 \mathrm{~g}, 73.63 \mathrm{mmol})$ was added to the reaction mixture followed by $\operatorname{EtBr}(6.388 \mathrm{~g}, 58.63 \mathrm{mmol})$. The color of the solution changed to red. After completing the addition, the resulting mixture was stirred at reflux for $5 \mathrm{~h}$. The reaction mixture was cooled to room temperature and the organic phase was extracted with diethyl ether (75 mL). The organic layer was dried over $\mathrm{MgSO}_{4}$ and the solvent was removed under reduced pressure. The crude product was purified by column chromatography on silica, eluting with $\mathrm{CH}_{2} \mathrm{Cl}_{2} /$ petrol (1:1) to afford $1(1.485 \mathrm{~g}, 75 \%)$ as a yellow oil. HR ESI MS [ $\left.\mathrm{C}_{18} \mathrm{H}_{18} \mathrm{O}_{2}\right]$ : Calcd. 266.1307, found 266.1302. IR (liquid): 1323, $1107 v(\mathrm{C}-\mathrm{O})$. UV-Vis $\left(\mathrm{CHCl}_{3}\right): 304$ [25.31], 341 [5.75], and 358 [4.41]. ${ }^{1} \mathrm{H}-\mathrm{NMR}\left(\mathrm{CDCl}_{3}\right)$ : $\delta 1.51\left(\mathrm{t},{ }^{3} J_{H H}=8 \mathrm{~Hz}\right)\left[6 \mathrm{H}, 2 \times \mathrm{CH}_{3}\right], 4.31\left(\mathrm{q},{ }^{3} J_{H H}=8 \mathrm{~Hz}\right)\left[4 \mathrm{H}, 2 \times \mathrm{OCH}_{2}\right], 7.60(\mathrm{~m})\left[4 \mathrm{H}, \mathrm{H}_{4}\right.$ and $\left.\mathrm{H}_{5}\right], 8.26\left(\mathrm{~d},{ }^{3} \mathrm{~J}_{\mathrm{HH}}=8 \mathrm{~Hz}\right)\left[2 \mathrm{H}, \mathrm{H}_{6}\right]$, and $8.64\left(\mathrm{~d},{ }^{3} \mathrm{~J}_{\mathrm{HH}}=8 \mathrm{~Hz}\right)\left[2 \mathrm{H}, \mathrm{H}_{3}\right] .{ }^{13} \mathrm{C}-\mathrm{NMR}\left(\mathrm{CDCl}_{3}\right): 15.94$ $\left(2 \mathrm{C}, 2 \times \mathrm{CH}_{3}\right), 69.04\left(2 \mathrm{C}, 2 \times \mathrm{OCH}_{2}\right), 122.37\left(2 \mathrm{C}, \mathrm{C}_{5}\right), 125.67\left(2 \mathrm{C}, \mathrm{C}_{6}\right), 126.72\left(2 \mathrm{C}, \mathrm{C}_{3}\right), 128.63\left(4 \mathrm{C}, \mathrm{C}_{2}-\mathrm{C}_{7}\right)$, $129.75\left(2 \mathrm{C}, \mathrm{C}_{4}\right)$, and $143.08\left(2 \mathrm{C}, \mathrm{C}_{1}\right)$.

Synthesis of 3,6-dibromo-9,10-diethoxyphenanthrene (2). A mixture of bromine (2.315 g, $14.28 \mathrm{mmol})$ and $\mathrm{CH}_{2} \mathrm{Cl}_{2}(70 \mathrm{~mL})$ was added dropwise to a solution of $\mathbf{1}(1.927 \mathrm{~g}, 7.14 \mathrm{mmol})$ in $\mathrm{CH}_{2} \mathrm{Cl}_{2}(30 \mathrm{~mL})$ over $1 \mathrm{~h}$ at room temperature, and the resultant mixture was stirred for a further $20 \mathrm{~min}$. The reaction mixture was washed with a solution of $\mathrm{Na}_{2} \mathrm{SO}_{3}(30 \mathrm{~mL}, 1.0 \mathrm{M})$, and the organic phase was collected and dried over $\mathrm{MgSO}_{4}$. The solvent was reduced in volume under reduced pressure and the crude product was purified by column chromatography on silica, eluting with $\mathrm{CH}_{2} \mathrm{Cl}_{2}$ /petrol (1:1) to afford $2(1.97 \mathrm{~g}, 64 \%)$ as a yellow powder. HR ESI MS [ $\left.\mathrm{C}_{18} \mathrm{H}_{16}{ }^{79} \mathrm{Br}_{2} \mathrm{O}_{2}\right]$ : Calcd. 421.9517, found 421.9518. HR ESI MS [ $\mathrm{C}_{18} \mathrm{H}_{16}{ }^{79} \mathrm{Br}^{81} \mathrm{BrO}_{2}$ ]: Calcd. 423.9497, found 423.9498. HR ESI MS [C $\left.{ }_{18} \mathrm{H}_{16}{ }^{81} \mathrm{Br}_{2} \mathrm{O}_{2}\right]:$ Calcd. 425.9476, found 425.9478. Elemental analysis for $\mathrm{C}_{18} \mathrm{H}_{16} \mathrm{Br}_{2} \mathrm{O}_{2}$, Calcd (found): $\mathrm{C}, 50.97$ (50.52); $\mathrm{H}, 3.80$ (3.48). IR (solid): $1614 \mathrm{~cm}^{-1} v(\mathrm{C}=\mathrm{C}), 1345 \mathrm{v}(\mathrm{C}-\mathrm{O})$, and $813 v(\mathrm{C}-\mathrm{Br}) . \mathrm{UV}-\mathrm{Vis}\left(\mathrm{CHCl}_{3}\right): 304$ [1.26], 316 [1.29], and 354 [1.69]. ${ }^{1} \mathrm{H}-\mathrm{NMR}\left(\mathrm{CDCl}_{3}\right): \delta 1.49\left(\mathrm{t},{ }^{3} J_{\mathrm{HH}}=7 \mathrm{~Hz}\right)\left[6 \mathrm{H}, 2 \times \mathrm{CH}_{3}\right], 4.28\left(\mathrm{q},{ }^{3} J_{\mathrm{HH}}=7 \mathrm{~Hz}\right)$ $\left[4 \mathrm{H}, 2 \times \mathrm{OCH}_{2}\right], 7.71\left(\mathrm{dd},{ }^{3} J_{H H}=9 \mathrm{~Hz},{ }^{4} J_{H H}=2 \mathrm{~Hz}\right)\left[2 \mathrm{H}, \mathrm{H}_{4}\right], 8.12\left(\mathrm{~d},{ }^{3} J_{H H}=9 \mathrm{~Hz}\right)\left[2 \mathrm{H}, \mathrm{H}_{6}\right]$, and $8.66\left(\mathrm{~d},{ }^{4} J_{\mathrm{HH}}=2 \mathrm{~Hz}\right)\left[2 \mathrm{H}, \mathrm{H}_{3}\right] .{ }^{13} \mathrm{C}-\mathrm{NMR}\left(\mathrm{CDCl}_{3}\right): 15.87\left(2 \mathrm{C}, 2 \times \mathrm{CH}_{3}\right), 69.16\left(2 \mathrm{C}, 2 \times \mathrm{OCH}_{2}\right), 120.37$ $\left(2 \mathrm{C}, \mathrm{C}_{4}\right), 124.30\left(2 \mathrm{C}, \mathrm{C}_{6}\right), 125.39\left(2 \mathrm{C}, \mathrm{C}_{3}\right), 127.42,128.86\left(4 \mathrm{C}, \mathrm{C}_{2}-\mathrm{C}_{7}\right), 130.50\left(2 \mathrm{C}, \mathrm{C}_{5}\right)$, and $142.89\left(2 \mathrm{C}, \mathrm{C}_{1}\right)$.

Synthesis of 3,6-bis(trimethylsilylethynyl)-9,10-diethoxyphenanthrene (3). Trimethylsilylacetylene $(0.174 \mathrm{~g}, 1.77 \mathrm{mmol})$, trans-PdCl${ }_{2}\left(\mathrm{PPh}_{3}\right)_{2}(0.041 \mathrm{~g}, 0.05 \mathrm{mmol})$ and $\mathrm{CuI}(0.005 \mathrm{~g}, 0.02 \mathrm{mmol})$ were added to a solution of compound $2(0.376 \mathrm{~g}, 0.88 \mathrm{mmol})$ in $\mathrm{NEt}_{3}(15 \mathrm{~mL})$ under a $\mathrm{N}_{2}$ atmosphere, and the mixture was stirred at $50^{\circ} \mathrm{C}$ overnight. The solvent was reduced in volume under reduced pressure and the crude product was purified by column chromatography on silica, eluting with $\mathrm{CH}_{2} \mathrm{Cl}_{2} /$ petrol (1:1) to afford $3(0.391 \mathrm{~g}, 96 \%)$ as a yellow solid. HR ESI MS [ $\left.\mathrm{C}_{28} \mathrm{H}_{34} \mathrm{O}_{2} \mathrm{Si}_{2}\right]$ : Calcd. 458.2097, found 458.2098. Elemental analysis for $\mathrm{C}_{28} \mathrm{H}_{34} \mathrm{O}_{2} \mathrm{Si}_{2}$, Calcd (found): C, 73.31 (73.04) and $\mathrm{H}, 7.47$ (7.11). IR (solid): $2157 v(\mathrm{C} \equiv \mathrm{C})$. UV-Vis $\left(\mathrm{CHCl}_{3}\right): 319$ [1.20], 332 [1.84], and 348 [1.69]. ${ }^{1} \mathrm{H}-\mathrm{NMR}\left(\mathrm{CDCl}_{3}\right): \delta 0.31(\mathrm{~s}, 9 \mathrm{H}$, $\left.\mathrm{SiMe}_{3}\right), 1.52\left(\mathrm{t},{ }^{3} J_{\mathrm{HH}}=7 \mathrm{~Hz}\right)\left[6 \mathrm{H}, 2 \times \mathrm{CH}_{3}\right], 4.30\left(\mathrm{q},{ }^{3} J_{\mathrm{HH}}=7 \mathrm{~Hz}\right)\left[4 \mathrm{H}, 2 \times \mathrm{OCH}_{2}\right], 7.66\left(\mathrm{dd},{ }^{3} J_{H H}=9 \mathrm{~Hz}\right.$, $\left.{ }^{4} J_{H H}=2 \mathrm{~Hz}\right)\left[2 \mathrm{H}, \mathrm{H}_{4}\right], 8.15\left(\mathrm{~d},{ }^{3} J_{\mathrm{HH}}=9 \mathrm{~Hz}\right)\left[2 \mathrm{H}, \mathrm{H}_{6}\right]$, and $8.73\left(\mathrm{~d},{ }^{4} J_{H H}=2 \mathrm{~Hz}\right)\left[2 \mathrm{H}, \mathrm{H}_{3}\right] .{ }^{13} \mathrm{C}-\mathrm{NMR}$ 
$\left(\mathrm{CDCl}_{3}\right): 0.00\left(3 \mathrm{C}, \mathrm{SiMe}_{3}\right), 15.84\left(2 \mathrm{C}, 2 \times \mathrm{CH}_{3}\right), 69.09\left(2 \mathrm{C}, 2 \times \mathrm{OCH}_{2}\right), 94.83\left(2 \mathrm{C}, \mathrm{C}_{9}\right), 105.51\left(2 \mathrm{C}, \mathrm{C}_{8}\right)$, $120.44\left(2 \mathrm{C}, \mathrm{C}_{5}\right), 122.31\left(2 \mathrm{C}, \mathrm{C}_{4}\right), 126.61\left(2 \mathrm{C}, \mathrm{C}_{6}\right), 127.61\left(2 \mathrm{C}, \mathrm{C}_{3}\right), 129.60\left(2 \mathrm{C}, \mathrm{C}_{7}\right), 129.98\left(2 \mathrm{C}, \mathrm{C}_{2}\right)$, and $143.62\left(2 \mathrm{C}, \mathrm{C}_{1}\right)$.

Synthesis of 3,6-diethynyl-9,10-diethoxyphenanthrene (4). Compound 3 (2.649 $\mathrm{g}, 5.77 \mathrm{mmol})$ and $\mathrm{K}_{2} \mathrm{CO}_{3}(4.791 \mathrm{~g}, 34.67 \mathrm{mmol})$ were stirred in a mixture of methanol $(20 \mathrm{~mL})$ and dichloromethane $\left(20 \mathrm{~mL}\right.$ ) under $\mathrm{N}_{2}$ at room temperature for $6 \mathrm{~h}$. The solvent was reduced in volume under reduced pressure and the crude product was purified by column chromatography on silica, eluting with $\mathrm{CH}_{2} \mathrm{Cl}_{2}$ /petrol (1:1) to afford 4 (1.338 g, 92\%) as a yellow solid. HR ESI MS [C $\left.{ }_{22} \mathrm{H}_{18} \mathrm{O}_{2}\right]$ : Calcd. 314.1307, found 314.1308. Elemental analysis for $\mathrm{C}_{22} \mathrm{H}_{18} \mathrm{O}_{2}$, Calcd (found): C, 84.05 (83.96) and H, 5.77 (5.41). IR (solid): $3292 \vee(\equiv \mathrm{C}-\mathrm{H})$ and $2154 \mathrm{v}(\mathrm{C} \equiv \mathrm{C})$. UV-Vis $\left(\mathrm{CHCl}_{3}\right)$ : sh 316 [1.67], 323 [2.17], and 338 [1.88]. ${ }^{1} \mathrm{H}-\mathrm{NMR}\left(\mathrm{CDCl}_{3}\right): \delta 1.48\left(\mathrm{t},{ }^{3} \mathrm{~J}_{\mathrm{HH}}=15 \mathrm{~Hz}\right)\left[6 \mathrm{H}, 2 \times \mathrm{CH}_{3}\right], 3.19(\mathrm{~s})\left[2 \mathrm{H}, \mathrm{H}_{9}\right], 4.30\left(\mathrm{q},{ }^{3} J_{\mathrm{HH}}=15 \mathrm{~Hz}\right)$ $\left[4 \mathrm{H}, 2 \times \mathrm{OCH}_{2}\right], 7.69\left(\mathrm{dd},{ }^{3} J_{H H}=18 \mathrm{~Hz},{ }^{4} J_{H H}=3 \mathrm{~Hz}\right)\left[2 \mathrm{H}, \mathrm{H}_{4}\right], 8.19\left(\mathrm{~d},{ }^{3} J_{H H}=18 \mathrm{~Hz}\right)\left[2 \mathrm{H}, \mathrm{H}_{6}\right]$, and $8.74\left(\mathrm{~d},{ }^{4} J_{\mathrm{HH}}=3 \mathrm{~Hz}\right)\left[2 \mathrm{H}, \mathrm{H}_{3}\right] .{ }^{13} \mathrm{C}-\mathrm{NMR}\left(\mathrm{CDCl}_{3}\right): 15.86\left(2 \mathrm{C}, 2 \times \mathrm{CH}_{3}\right), 69.18\left(2 \mathrm{C}, 2 \times \mathrm{OCH}_{2}\right), 77.74$ $\left(2 \mathrm{C}, \mathrm{C}_{8}\right), 84.12\left(2 \mathrm{C}, \mathrm{C}_{9}\right), 119.57\left(2 \mathrm{C}, \mathrm{C}_{5}\right), 122.59\left(2 \mathrm{C}, \mathrm{C}_{4}\right), 126.92\left(2 \mathrm{C}, \mathrm{C}_{6}\right), 127.64\left(2 \mathrm{C}, \mathrm{C}_{3}\right), 129.98\left(2 \mathrm{C}, \mathrm{C}_{7}\right)$, $130.09\left(2 \mathrm{C}, \mathrm{C}_{2}\right)$, and $143.73\left(2 \mathrm{C}, \mathrm{C}_{1}\right)$.

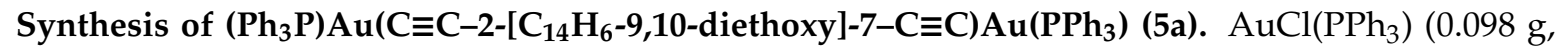
$0.19 \mathrm{mmol})$ and $\mathrm{Bu}^{t} \mathrm{OK}(0.085 \mathrm{~g}, 0.19 \mathrm{mmol})$ were added to a solution of compound $4(0.031 \mathrm{~g}$, $0.099 \mathrm{mmol})$ in methanol $(15 \mathrm{~mL})$ under a $\mathrm{N}_{2}$ atmosphere and the mixture was stirred overnight. The solvent was reduced in volume under reduced pressure and the crude product was purified by column chromatography on silica, eluting with $\mathrm{CH}_{2} \mathrm{Cl}_{2} /$ petrol (1:1) to afford $5 \mathrm{a}(0.099 \mathrm{~g}, 82 \%)$ as a yellow powder. HR ESI MS [ $\left.\mathrm{C}_{58} \mathrm{H}_{47}{ }^{197} \mathrm{Au}_{2} \mathrm{O}_{2} \mathrm{P}_{2}\right]$ : Calcd. 1231.2382, found 1231.2382. Elemental analysis for $\mathrm{C}_{58} \mathrm{H}_{47} \mathrm{Au}_{2} \mathrm{O}_{2} \mathrm{P}_{2}$, Calcd (found): C, 56.60 (56.27) and H, 3.77 (3.60). IR (solid): 2096 v(C $\equiv \mathrm{C}$ ). UV-Vis $\left(\mathrm{CHCl}_{3}\right)$ : sh 328 [2.04], 343 [3.04], and 363 [2.79]. ${ }^{1} \mathrm{H}-\mathrm{NMR}\left(\mathrm{CDCl}_{3}\right): \delta 1.48\left(\mathrm{t},{ }^{3} J_{\mathrm{HH}}=8 \mathrm{~Hz}\right)$ $\left[6 \mathrm{H}, 2 \times \mathrm{CH}_{3}\right], 4.26\left(\mathrm{q},{ }^{3} J_{H H}=7 \mathrm{~Hz}\right)\left[4 \mathrm{H}, 2 \times \mathrm{OCH}_{2}\right], 7.62-7.46(\mathrm{~m})\left[30 \mathrm{H}, 2 \times \mathrm{PPh}_{3}\right], 7.71\left(\mathrm{dd},{ }^{3} J_{H H}=8 \mathrm{~Hz}\right.$, $\left.{ }^{4} J_{H H}=1 \mathrm{~Hz}\right)\left[2 \mathrm{H}, \mathrm{H}_{4}\right], 8.08\left(\mathrm{~d},{ }^{3} J_{H H}=8 \mathrm{~Hz}\right)\left[2 \mathrm{H}, \mathrm{H}_{6}\right]$, and $8.78\left(\mathrm{~d},{ }^{4} J_{H H}=1 \mathrm{~Hz}\right)\left[2 \mathrm{H}, \mathrm{H}_{3}\right] .{ }^{13} \mathrm{C}-\mathrm{NMR}$ $\left(\mathrm{CDCl}_{3}\right): 15.95\left(2 \mathrm{C}, 2 \times \mathrm{CH}_{3}\right), 69.02\left(2 \mathrm{C}, 2 \times \mathrm{OCH}_{2}\right), 128.01\left(2 \mathrm{C}, \mathrm{C}_{8}\right), 129.13,129.18,129.22,129.28$ $\left(36 \mathrm{C}, 2 \times \mathrm{PPh}_{3}\right), 129.77\left(2 \mathrm{C}, \mathrm{C}_{5}\right) 130.04\left(2 \mathrm{C}, \mathrm{C}_{4}\right), 131.52\left(2 \mathrm{C}, \mathrm{C}_{9}\right)$ 134.14, $134.21\left(4 \mathrm{C}, \mathrm{C}_{3}-\mathrm{C}_{6}\right), 134.38,134.44$ $\left(4 \mathrm{C}, \mathrm{C}_{2}-\mathrm{C}_{7}\right)$, and $143.29\left(2 \mathrm{C}, \mathrm{C}_{1}\right) .{ }^{31} \mathrm{P}-\mathrm{NMR}: \delta 42.35(\mathrm{~s})$.

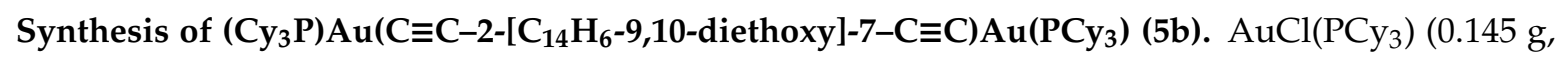
$0.283 \mathrm{mmol})$ and $\mathrm{Bu}^{t} \mathrm{OK}(0.091 \mathrm{~g}, 0.811 \mathrm{mmol})$ were added to a solution of compound $4(0.044 \mathrm{~g}$, $0.140 \mathrm{mmol})$ in methanol $(15 \mathrm{~mL})$ under a $\mathrm{N}_{2}$ atmosphere and the mixture was stirred overnight. Reduction in volume of the solvent afforded a solid residue that was dissolved in $\mathrm{CH}_{2} \mathrm{Cl}_{2}$ and precipitated by adding ether, to afford $5 \mathbf{b}(0.131 \mathrm{~g}, 74 \%)$ as a yellow powder. HR ESI MS $\left[\mathrm{C}_{58} \mathrm{H}_{83}{ }^{197} \mathrm{Au}_{2} \mathrm{O}_{2} \mathrm{P}_{2}\right]$ : Calcd. 1267.5200, found 1267.5192. Elemental analysis for $\mathrm{C}_{58} \mathrm{H}_{83} \mathrm{Au}_{2} \mathrm{O}_{2} \mathrm{P}_{2}$, Calcd (found): C, 54.98 (55.11) and H, 6.52 (6.22). IR (solid): $2100 v(\mathrm{C} \equiv \mathrm{C})$. UV-Vis $\left(\mathrm{CHCl}_{3}\right): 327$ [1.47], 342 [2.25], and 360 [1.89]. ${ }^{1} \mathrm{H}-\mathrm{NMR}\left(\mathrm{CDCl}_{3}\right): \delta 1.46\left(\mathrm{t},{ }^{3} J_{\mathrm{HH}}=7 \mathrm{~Hz}\right)\left[6 \mathrm{H}, 2 \times \mathrm{CH}_{3}\right], 1.25-2.10(\mathrm{~m})$ $\left[66 \mathrm{H}, 2 \times \mathrm{PCy}_{3}\right], 4.25\left(\mathrm{q},{ }^{3} J_{\mathrm{HH}}=7 \mathrm{~Hz}\right)\left[4 \mathrm{H}, 2 \times \mathrm{OCH}_{2}\right], 7.68\left(\mathrm{dd},{ }^{3} J_{H H}=9 \mathrm{~Hz},{ }^{4} J_{H H}=2 \mathrm{~Hz}\right)\left[2 \mathrm{H}, \mathrm{H}_{4}\right], 8.05$ $\left(\mathrm{d},{ }^{3} J_{\mathrm{HH}}=9 \mathrm{~Hz}\right)\left[2 \mathrm{H}, \mathrm{H}_{6}\right]$, and $8.75\left(\mathrm{~d},{ }^{4} \mathrm{~J}_{\mathrm{HH}}=2 \mathrm{~Hz}\right)\left[2 \mathrm{H}, \mathrm{H}_{3}\right] .{ }^{13} \mathrm{C}-\mathrm{NMR}\left(\mathrm{CDCl}_{3}\right): 15.94\left(2 \mathrm{C}, 2 \times \mathrm{CH}_{3}\right)$, 25.93, 26.95, 27.00, 27.14, 27.20, 30.72, 30.77, 33.15, 33.28 (36C, $\left.2 \times \mathrm{PCy}_{3}\right), 68.69\left(2 \mathrm{C}, 2 \times \mathrm{OCH}_{2}\right), 104.36$ $\left(2 \mathrm{C}, \mathrm{C}_{8}\right), 121.66,122.48,127.97,128.19,130.60\left(14 \mathrm{C}, \mathrm{C}_{2}, \mathrm{C}_{3}, \mathrm{C}_{4}, \mathrm{C}_{5}, \mathrm{C}_{6}, \mathrm{C}_{7}\right), 143.00\left(2 \mathrm{C}, \mathrm{C}_{1}\right)$, and $\mathrm{C}_{9}$ is not observed. ${ }^{31} \mathrm{P}-\mathrm{NMR}: \delta 56.31(\mathrm{~s})$.

\subsection{DNA Binding Studies}

\subsubsection{Determination of the DNA Binding Constant using UV-Vis Absorption}

The concentration of the ct-DNA stock solution in distilled water was determined from the reported molar absorptivity at $260 \mathrm{~nm}\left(6600 \mathrm{M}^{-1} \mathrm{~cm}^{-1}\right)$. The ratio of absorbance at 260 to that at $280 \mathrm{~nm}$ (1.8) confirmed that the DNA was free from protein impurities [55]. Spectroscopic studies were conducted by maintaining the concentrations of the compounds at a constant value $(20 \mu \mathrm{M})$ 
while varying the concentration of ct-DNA (minimum amount of DMSO was employed to maintain the compounds solubility during the experiment). The spectroscopic responses were tracked after allowing the solution to incubate for $2 \mathrm{~min}$. A pH value of 7.4 was maintained in all the experiments using phosphate buffer. From the absorbance values, the Benesi-Hildebrand equation (Equation (1)) was used to evaluate the binding constants $\left(\mathrm{K}_{\mathrm{b}}\right)$ of the compounds with ct-DNA [56].

$$
\left[\mathrm{A}_{\mathrm{o}} /\left(\mathrm{A}-\mathrm{A}_{\mathrm{o}}\right)\right]=\left[\varepsilon_{\mathrm{g}} /\left(\varepsilon_{\mathrm{h}-\mathrm{g}}-\varepsilon_{\mathrm{g}}\right)\right]+\left\{\left[\varepsilon_{\mathrm{g}} /\left(\varepsilon_{\mathrm{h}-\mathrm{g}}-\varepsilon_{\mathrm{g}}\right)\right] \times\left[1 /\left(\mathrm{K}_{\mathrm{b}}[\mathrm{DNA}]\right)\right\}\right.
$$

$\mathrm{A}_{\mathrm{o}} / \mathrm{A}-\mathrm{A}_{\mathrm{o}}$ was plotted against $1 /[\mathrm{DNA}]$, and the $\mathrm{K}_{\mathrm{b}}$ values were calculated from the ratio of the intercept to the slope [56] $\left(\mathrm{A}_{\mathrm{o}}\right.$ and $\mathrm{A}$ are the absorbance values of the compounds in the absence and presence of ct-DNA, respectively).

\subsubsection{Determining the Mode of Interaction by Fluorescence}

Solutions of $\mathbf{4}, \mathbf{5 a}$, and $\mathbf{5 b}$ of the same concentration $\left(1.00 \times 10^{-5} \mathrm{M}\right)$ in the minimum amount of DMSO in buffer solutions were treated with varying amounts of ct-DNA solution in buffer, and the emission spectra were monitored [57].

\subsection{Molecular Docking Studies}

Molecular Operating Environment (MOE) 2008.10 (Chemical Computing Group Inc., Quebec, Canada, 2008) was used to perform the molecular docking studies. A Gaussian contact surface was drawn around the binding sites enclosing the van der Waals surface. Docking studies were undertaken to assess the binding free energy of the complexes inside the DNA. The docking scores were first acquired utilizing the London $\mathrm{dG}$ scoring function in the MOE software, and then were improved using two unrelated refinement methods. The Grid-Min pose and Force-Field were employed to confirm that the refined poses of the complexes were geometrically correct. Bond rotations were allowed, and the best five binding poses were then examined. The docking poses of the ethidium bromide, $\mathbf{4}, \mathbf{5 a}, \mathbf{5} \mathbf{b}$ and the co-crystallized structure of the B-DNA were docked (RSCP PDB code: 1BNA). RMSD values were used to assess the best binding pose.

\subsection{Anticancer Activity and Cytotoxcicity}

The cells were provided by the Egyptian Holding Company for Biological Products and Vaccines (VACSERA), Giza, Egypt, and were maintain in a tissue culture unit. The growth of the cells was undertaken in a RBMI-1640 medium, sourced with $10 \%$ heat inactivated FBS, 50 units $/ \mathrm{mL}$ of penicillin, and $50 \mathrm{mg} / \mathrm{mL}$ of streptomycin, and reserved in a humidified atmosphere containing $5 \% \mathrm{CO}_{2}[58,59]$. The cells were kept as a monolayer culture by serial subculturing. Cell culture reagents were obtained from Lonza (Basel, Switzerland). The assessment of the anticancer activity of the compounds was obtained against the MCF-7 cell line (breast cancer), HEPG-2 cell line (liver cancer), PC-3 cell line (prostate cancer), and MOLT-4 cells (leukemia).

The sulforhodamine B (SRB) was used to determine cytotoxicity using the assay method, as previously described by Skehan et al. [60]. Collections of cells were subcultured using $0.25 \%$ trypsin-EDTA, and then seeded in 96-well plates at 1000 to 2000 cells/well in a RBMI-1640-supplemented medium. After $24 \mathrm{~h}$, the cells were incubated for $72 \mathrm{~h}$ at five different concentrations of the synthesized compounds $\left(10^{-4}, 10^{-5}, 10^{-6}, 10^{-7}, 10^{-8} \mathrm{M}\right)$ in DMSO. After $72 \mathrm{~h}$ treatments, the cells were fixed with $10 \%$ trichloroacetic acid for $1 \mathrm{~h}$ at $4{ }^{\circ} \mathrm{C}$. Wells were stained for $10 \mathrm{~min}$ at room temperature with $0.4 \%$ SRB (sulforhodamine B) dissolved in $1 \%$ acetic acid. The plates were subjected to air drying for $24 \mathrm{~h}$, and the dye was solubilized with Tris hydrochloride for 5 min using a shaker at $1600 \mathrm{rpm}$. The OD (optical density) of each well was measured spectrophotometrically at $564 \mathrm{~nm}$ with an ELISA microplate reader (ChroMate 4300, Awareness Technology, FL, USA). Calculations of IC50 values were obtained from a Boltzmann sigmoidal equation for the response as a function of the concentration, using nonlinear regression fitting models (Graph Pad, Prism Version 5). 


\section{Conclusions}

In this article, we have described the synthesis of 3,6-diethynyl-9,10-diethoxyphenanthrene from phenanthrene together with two binuclear gold(I) complexes obtained via metal alkynyl bond-formation reactions. Spectroscopic studies (absorption and emission) were carried out for the metal complexes and their acetylene ligand, showing a red shift in the absorption maxima and emission wavelength of the ligand upon complexation. The calculated $\mathrm{K}_{\mathrm{b}}$ values of the compounds showed that the 3,6-diethynyl-9,10-diethoxyphenanthrene (4) has better binding affinity toward ct-DNA than ethidium bromide. Functionalizing the phenanthrenyl ligand with $\mathrm{AuPPh}_{3}$ enhances the binding constant of the phenanthrenyl ligand while $\mathrm{AuPC}_{3}$ slightly diminishes the binding constant, an observation which can be attributed to the increased steric hindrance associated with the latter. According to the docking studies, 4 establishes pi-pi interactions with several deoxyadenosine (DA) and thymidine (DT) nucleotides in the two strands of the ct-DNA, in addition to donor-acceptor interactions of the acetylene and the deoxyadenosine (DA) nucleotides. In contrast, the gold complexes interact with nucleotides from one strand of the DNA, forming several pi-pi interactions. The results of the molecular docking studies show good agreement with the experimental findings of the DNA-binding study. The anticancer screening of the gold complexes against four cell lines showed remarkable and promising cytotoxicity as compared with that of cisplatin.

In conclusion, a strongly intercalating phenanthrenyl system has been synthesized which has the potential to be decorated with diverse metal centers through metal-alkynyl bond formation. The functionalization of the phenanthrenyl system with the gold centers has introduced promising anticancer activities while maintaining the DNA binding capabilities. The two components (phenanthrenyl and metal centers) of our complexes can be altered independently. To improve the binding (targeting) of the complex, the phenanthrenyl-based ligand can be modified while the anticancer properties (including the physicochemical properties) can be fine-tuned by modifying the metal centers and the co-ligands.

Supplementary Materials: The following are available online, Figure S1: HR Mass spectrometry of Compound 1, Figure S2: IR of Compound 1, Figure S3: H-NMR of Compound 1, Figure S4: CNMR of Compound 1, Figure S5: HR Mass spectrometry of Compound 2, Figure S6: HR Mass spectrometry of Compound 2, Figure S7: HR Mass spectrometry of Compound 2, Figure S8: IR of Compound 2, Figure S9: HNMR of Compound 2, Figure S10: CNMR of Compound 2, Figure S11: HR Mass spectrometry of Compound 3, Figure S12: IR of Compound 3, Figure S13: HNMR of Compound 3, Figure S14: CNMR of Compound 3, Figure S15: HR Mass spectrometry of Compound 4, Figure S16: IR of Compound 4, Figure S17: HNMR of Compound 4, Figure S18: CNMR of Compound 4, Figure S19: HR Mass spectrometry of Compound 5a, Figure S20: IR of Compound 5a, Figure S21: HNMR of Compound 5a, Figure S22: CNMR of Compound 5a, Figure S23: PNMR of Compound 5a, Figure S25: HNMR of Compound 5b, Figure S24: HR Mass spectrometry of Compound 5b, Figure S26: CNMR of Compound 5b, Figure S27: PNMR of Compound 5b, Figure S28: HNMR of 3,6-dibromophenanthrerne-9,10-dione, Figure S29: CNMR of 3,6-dibromophenanthrerne-9,10-dione.

Author Contributions: Synthesis and characterizations, M.S.A.; DNA binding, M.A.H.; Anticancer studies, M.H.A.; Supervision and writing—original draft preparation, B.A.B.; writing-review and editing; M.G.H. All authors have read and agreed to the published version of the manuscript.

Funding: This project was funded by the Deanship of Scientific Research (DSR), King Abdulaziz University, Jeddah, Saudi Arabia under grant no. (KEP-44-130-40). The authors, therefore, acknowledge with thanks DSR technical and financial support.

Acknowledgments: This project was funded by the Deanship of Scientific Research (DSR), King Abdulaziz University, Jeddah, Saudi Arabia under grant no. (KEP-44-130-40). The authors, therefore, acknowledge with thanks DSR technical and financial support.

Conflicts of Interest: The authors declare no conflict of interest. 


\section{Abbreviations}

$\begin{array}{ll}\text { TG-CA } & \text { Thymine/guanine-cytosine/adenine. } \\ \text { Ct-DNA } & \text { calf-thymus DNA } \\ \text { MCF-7 } & \text { abbreviated from Michigan Cancer Foundation-7; a breast cancer cell line. } \\ \text { HEPG-2 } & \text { hepatic liver carcinoma cell line. } \\ \text { PC-3 } & \text { hhuman prostate cancer cell line. } \\ \text { MOLT-4 } & \text { Human acute lymphoblastic leukemia cell line. }\end{array}$

\section{References}

1. Cram, D.J. The discovery of crown ethers. J. Incl. Phenom. Macro. 1988, 6, 397-413. [CrossRef]

2. Cram, D.J. Molecular container compounds. Nature 1992, 356, 29-36. [CrossRef]

3. Lehn, J.-M.J. Supramolecular chemistry- scope and perspectives: Molecules—supermolecules-molecular devices. Incl. Phenom. Macro 1988, 6, 351-396. [CrossRef]

4. Lehn, J.-M. Constitutional dynamic chemistry: Bridge from supramolecular chemistry to adaptive chemistry. Top. Curr. Chem. 2012, 322, 1-32.

5. Pedersen, C.J. Macrocyclic polyethers and their complexes. Angew. Chem. Int. Ed. Engl. 1972, 11, 16-25. [CrossRef]

6. Zhou, J.; Yu, G.; Huang, F. Supramolecular chemotherapy based on host-guest molecular recognition: A novel strategy in the battle against cancer with a bright future. Chem. Soc. Rev. 2017, 46, 7021-7053. [CrossRef]

7. Chaires, J.B. Dissecting the free energy of drug binding to DNA. Anticancer Drug Des. 1996, 11, 569-680.

8. Hambley, T.W. Platinum binding to DNA: Structural controls and consequences. J. Chem. Soc. Dalton Trans. 2001, 19, 2711-2718. [CrossRef]

9. Brabec, V.; Novakova, O. DNA binding mode of ruthenium complexes and relationship to tumor cell toxicity. Drug Resist. Updates 2006, 9, 111-122. [CrossRef]

10. Xiong, Y.; Ji, L.-N. Synthesis, DNA-binding and DNA-mediated luminescence quenching of Ru(II) polypyridine complexes. Coord. Chem. Rev. 1999, 185-186, 711-733. [CrossRef]

11. Brissos, R.F.; Caubet, A.; Gamez, P. Possible DNA-Interacting Pathways for Metal-Based Compounds Exemplified with Copper Coordination Compounds. Eur. J. Inorg. Chem. 2015, 6, 2633-2645. [CrossRef]

12. Barone, G.; Terenzi, A.; Lauria, A.; Almerico, A.M.; Leal, J.M.; Busto, N.; Garcia, B. DNA-binding of nickel(II), copper(II) and zinc(II) complexes: Structure-affinity relationships. Coord. Chem. Rev. 2013, 257, 2848-2862. [CrossRef]

13. Amir, M.K.; Khan, S.Z.; Hayat, F.; Hassan, A.; Butler, I.S. Zia-ur-Rahman, Anticancer Activity, DNA-binding and DNA-denaturation Aptitude of Palladium(II) Dithiocarbamates. Inorg. Chim. Acta 2016, 451, 31-40. [CrossRef]

14. Zaki, M.; Arjmand, F.; Tabassum, S. Current and future potential of metallo drugs: Revisiting DNA-binding of metal containing molecules and their diverse mechanism of action. Inorg. Chim. Acta 2016, 444, 1-22. [CrossRef]

15. Wilson, W.D.; Jones, R.L. Intercalating drugs: DNA binding and molecular pharmacology. In Advances in Pharmacology; Silvio, A.G., Ed.; Academic Press: London, UK, 1981; Volume 13, pp. 177-222.

16. Rescifina, A.; Zagni, C.; Verrica, M.G.; Pistara, V.; Corsaro, A. Recent advances in small organic molecules as DNA intercalating agents: Synthesis, activity, and modeling. Eur. J. Med. Chem. 2014, 74, 95-115. [CrossRef]

17. Galind-Murillo, R.; Garcia-Ramos, J.C.; Ruiz-Azurara, L.; Cheatham, T.E.; Cortes-Guzman, F. Intercalation processes of copper complexes in DNA. Nucleic Acids Res. 2015, 43, 5364-5376. [CrossRef]

18. Sundaravadivel, E.; Reddy, G.R.; Manoj, D.; Rajendran, S.; Kandaswamy, M.; Janakiraman, M. DNA binding and cleavage studies of copper(II) complex containing $\mathrm{N}_{2} \mathrm{O}_{2}$ Schiff base ligand. Inorg. Chim. Acta 2018, 482, 170-178. [CrossRef]

19. Farhangian, H.; Moghadam, M.E.; Divsalar, A.; Rahiminezhad, A. Anticancer activity of novel amino acid derivative of palladium complex with phendione ligand against of human colon cancer cell line. J. Biol. Inorg. Chem. 2017, 22, 1055-1064. [CrossRef] 
20. Nikolic, S.; Rangasamy, L.; Gligorijevic, N.; Arandelovic, S.; Radulovic, S.; Gasser, G.; Grguric-Sipka, S. Synthesis, Characterization and Biological Evaluation of Novel Ru(II)-Arene Complexes Containing Intercalating Ligands. J. Inorg. Biochem. 2016, 160, 156-165. [CrossRef]

21. Valladolid, J.; Hortiguela, C.; Busto, N.; Espino, G.; Rodriguez, A.M.; Leal, J.M.; Jolan, F.A.; Manzano, B.R.; Carbayo, A.; Garcia, B. Phenanthroline ligands are biologically more active than their corresponding ruthenium(II) arene complexes. Dalton Trans. 2014, 43, 2629-2645. [CrossRef]

22. Busto, N.; Martinez-Alonso, M.; Leal, J.M.; Rodriguez, A.M.; Domingueze, F.; Acuna, M.I.; Espino, G.; Garcia, B. Monomer-Dimer Divergent Behavior toward DNA in a Half-Sandwich Ruthenium(II) Aqua Complex. Antiproliferative Biphasic Activity. Organometallics 2015, 34, 319-327. [CrossRef]

23. Ljubijankic, N.; Zahirovic, A.; Turkusic, E.; Kahrovic, E. DNA Binding Properties of Two Ruthenium(III) Complexes Containing Schiff Bases Derived from Salicylaldehyde: Spectroscopic and Electrochemical Evidence of CT DNA Intercalation. Croat. Chem. Acta 2013, 86, 215-222. [CrossRef]

24. Kocak, A.; Yilmaz, H.; Faiz, O.; Andac, O. Experimental and theoretical studies on Cu(II) complex of $\mathrm{N}, \mathrm{N}^{\prime}$-disalicylidene-2,3-diaminopyridine ligand reveal indirect evidence for DNA intercalation. Polyhedron 2016, 104, 106-115. [CrossRef]

25. Sharma, S.; Panjamurthy, K.; Choudhary, B.; Srivastava, M.; Shahabuddin, M.S.; Giri, R.; Advirao, G.M.; Roghavan, S.C. A novel DNA intercalator, 8-methoxy pyrimido $\left[4^{\prime}, 5^{\prime}: 4,5\right]$ thieno $(2,3-\mathrm{b})$ quinoline- $4(3 \mathrm{H})$-one induces apoptosis in cancer cells, inhibits the tumor progression and enhances lifespan in mice with tumor. Mol. Carcinog. 2013, 52, 413-425. [CrossRef] [PubMed]

26. Banik, B.K.; Becker, F.F. Synthesis, electrophilic substitution and structure-activity relationship studies of polycyclic aromatic compounds towards the development of anticancer agents. Curr. Med. Chem. 2001, 8, 1513-1533. [CrossRef] [PubMed]

27. Holmlin, R.E.; Dendliker, P.J.; Barton, J.K. Synthesis of metallointercalator-DNA conjugates on a solid support. Bioconj. Chem. 1999, 10, 1122-1130. [CrossRef]

28. Notaro, A.; Gasser, G. Monomeric and dimeric coordinatively saturated and substitutionally inert Ru(ii) polypyridyl complexes as anticancer drug candidates. Chem. Soc. Rev. 2017, 46, 7317-7337. [CrossRef]

29. Zhao, C.Q.; Sun, Y.H.; Ren, J.S.; Qu, X.G. Recent progress in lanthanide complexes for DNA sensing and targeting specific DNA structures. Inorg. Chim. Acta 2016, 452, 50-61. [CrossRef]

30. Esmail, S.A.A.; Shamsi, M.; Chen, T.; Al-asbahy, W.M. Design, synthesis and characterization of Tin-based cancer chemotherapy drug entity; in vitro DNA binding, cleavage studies, induce cancer cell apoptosis by triggering DNA damage-mediated p53 phosphorylation and Molecular docking studies. Appl. Organomet. Chem. 2018, 33, e4651. [CrossRef]

31. Wong, E.; Giandomenico, C.M. Current status of platinum-based antitumor drugs. Chem. Rev. 1999, 99, 2451-2466. [CrossRef]

32. Dasari, S.; Tchounwou, P.B. Cisplatin in cancer therapy: Molecular mechanisms of action. Eur. J. Pharmacol. 2014, 740, 364-378. [CrossRef] [PubMed]

33. Wang, X.Y.; Guo, Z.J. Towards the rational design of platinum(ii) and gold(iii) complexes as antitumour agents. Dalton Trans. 2008, 12, 1521-1532. [CrossRef] [PubMed]

34. Rabik, C.A.; Dolan, M.E. Molecular mechanisms of resistance and toxicity associated with platinating agents. Cancer Treat. Rev. 2007, 33, 9-23. [CrossRef] [PubMed]

35. Heffeter, P.; Jungwirth, U.; Jakupec, M.; Hartinger, C.; Galanski, M.; Elbling, L.; Micksche, M.; Keppler, B.; Berger, W. Resistance against novel anticancer metal compounds: Differences and similarities. Drug Resist. Updates 2008, 11, 1-16. [CrossRef]

36. Meyer, A.; Gutierrez, A.; Ott, I.; Rodriguez, L. Phosphine-bridged dinuclear gold(I) alkynyl complexes: Thioredoxin reductase inhibition and cytotoxicity. Inorg. Chim. Acta 2013, 398, 72-76. [CrossRef]

37. Andermark, V.; Goke, K.; Kokoschka, M.; Abu el Maaty, M.A.; Lum, C.T.; Zou, T.; Sun, R.W.-Y.; Aguilo, E.; Oehninger, L.; Rodriguez, L.; et al. Alkynyl gold(I) phosphane complexes: Evaluation of structure-activity-relationships for the phosphane ligands, effects on key signaling proteins and preliminary in-vivo studies with a nanoformulated complex. J. Inorg. Biochem. 2016, 160, 140-148. [CrossRef]

38. Marmol, I.; Virumbrales-Munoz, M.; Quero, J.; Sánchez-de-Diego, C.; Fernández, L.; Ochoa, I.; Cerrada, E.; Yoldi, M.J.R. Alkynyl gold(I) complex triggers necroptosis via ROS generation in colorectal carcinoma cells. J. Inorg. Biochem. 2017, 176, 123-133. [CrossRef]

39. Shaw, C.F. Gold-Based Therapeutic Agents. Chem. Rev. 1999, 99, 2589-2600. [CrossRef] 
40. Bagowski, C.P.; You, Y.; Scheffler, H.; Velcken, D.H.; Schmitz, D.J.; Ott, I. Naphthalimide gold(I) phosphine complexes as anticancer metallodrugs. Dalton Trans. 2009, 48, 10799-10805. [CrossRef]

41. Abas, E.; Espallargas, N.; Burbello, G.; Mesonero, J.E.; Rodriguez-Dieguez, A.; Grasa, L.; Laguna, M. Anticancer Activity of Alkynylgold(I) with $\mathrm{P}\left(\mathrm{NMe}_{2}\right)_{3}$ Phosphane in Mouse Colon Tumors and Human Colon Carcinoma Caco-2 Cell Line. Inorg. Chem. 2019, 58, 15536-15551. [CrossRef]

42. Marmol, I.; Castellnou, P.; Alvarez, R.; Gimeno, M.C.; Rodríguez-Yoldi, M.J.; Cerrada, E. Alkynyl gold(I) complexes derived from 3-hydroxyflavones as multi-targeted drugs against colon cancer. Eur. J. Med. Chem. 2019, 183, 111661. [CrossRef] [PubMed]

43. Caikovskii, V.K.; Filimonov, V.D.; Skorokhodov, V.I.; Ogorodnikov, V.D. Superactivity and dual reactivity of the system N-Iodosuccinimide-H2SO4 in the lodination of deactivated arenes. Russ. J. Org. Chem. 2007, 43, 1278-1281. [CrossRef]

44. Suh, Y.-G.; Lee, Y.-S.; Min, K.-H.; Park, O.-H.; Kim, J.-K.; Seung, H.-S.; Seo, S.-Y.; Lee, B.-Y.; Nam, Y.-H.; Lee, K.-O.; et al. Novel potent antagonists of transient receptor potential channel, vanilloid subfamily member 1: Structure-activity relationship of 1,3-diarylalkyl thioureas possessing new vanilloid equivalents. J. Med. Chem. 2005, 48, 5823-5836. [CrossRef] [PubMed]

45. Iskra, J.; Stavber, S.; Zupan, M. Nonmetal-Catalyzed Iodination of Arenes with Iodide and Hydrogen Peroxide. Synthesis 2004, 11, 1869-1873. [CrossRef]

46. Balasingham, R.G.; Williams, C.F.; Mottram, H.J.; Coogan, M.P.; Pope, S.J.A. Gold(I) Complexes Derived from Alkynyloxy-Substituted Anthraquinones: Syntheses, Luminescence, Preliminary Cytotoxicity, and Cell Imaging Studies. Organometallics. Organometallics 2012, 31, 5835-5843. [CrossRef]

47. Long, N.J.; Williams, C.H. Metal alkynyl $\sigma$ complexes: Synthesis and materials. Angew. Chem. Int. Ed. 2003, 42, 2586-2617. [CrossRef]

48. Karver, M.R.; Krishnamurthy, D.; Kulkarni, R.A.; Bottini, N.; Barrios, A.M. Identifying Potent, Selective protein tyrosine phosphatase inhibitors from a library of $\mathrm{Au}(\mathrm{I})$ complexes. J. Med. Chem. 2009, 52, 6912-6918. [CrossRef]

49. Barlow, A.; Babgi, B.; Samoc, M.; Corkery, T.C.; van Cleuvenbergen, S.; Asselberghs, I.; Clays, K.; Cifuentes, M.P.; Humphrey, M.G. Organometallic complexes for non-linear optics. 51. Second- and third-order non-linear optical properties of alkynylgold complexes. Aust. J. Chem. 2012, 65, 834-841. [CrossRef]

50. Chao, H.-Y.; Lu, W.; Li, Y.; Chan, M.C.W.; Che, C.-M.; Cheung, K.-K.; Zhu, N. Organic Triplet Emissions of Arylacetylide Moieties Harnessed through Coordination to $\left[\mathrm{Au}\left(\mathrm{PC}_{3}\right)\right]^{+}$. Effect of Molecular Structure upon Photoluminescent Properties. J. Am. Chem. Soc. 2002, 124, 14696-14706. [CrossRef]

51. Chui, C.-H.; Wong, R.S.-M.; Gambari, R.; Cheng, G.Y.-M.; Yuen, M.C.-W.; Chan, K.-W.; Tong, S.-W.; Lau, F.-Y.; Lai, P.B.-S.; Lam, K.-H.; et al. Antitumor activity of diethynylfluorene derivatives of gold(I). Bioorg. Med. Chem. 2009, 17, 7872. [CrossRef]

52. Ali, R.; Razi, S.S.; Shahid, M.; Srivastava, P.; Misra, A. Off-On-Off fluorescence behavior of an intramolecular charge transfer probe toward anions and $\mathrm{CO}_{2}$, Spectrochim. Acta A Mol. Biomol. Spec. 2016, 168, 21-28. [CrossRef] [PubMed]

53. Bruce, M.I.; Nicholsan, B.K.; Bin Shawkataly, O.; Shapley, J.R.; Henly, T. Synthesis of Gold-Containing Mixed-Metal Cluster Complexes. Inorg. Synth. 1989, 26, 324-328.

54. Isab, A.A.; Fettouhi, M.; Ahmad, S.; Ouahab, L. Mixed ligand gold (I) complexes of phosphines and thiourea and X-ray structure of (thiourea-kS)(tricyclohexylphosphine) gold (I) chloride. Polyhedron 2003, 22, 1349-1354. [CrossRef]

55. Pages, B.J.; Ang, D.L.; Wright, E.P.; Aldrich-Wright, J.R. Metal complex interactions with DNA. Dalton Trans. 2015, 44, 3505-3526. [CrossRef]

56. Wolfe, A.; Shimer, G.H.; Meehan, T. Polycyclic aromatic hydrocarbons physically intercalate into duplex regions of denatured DNA. Biochemistry 1987, 26, 6392-6396. [CrossRef]

57. Srishailam, A.; Kumar, Y.P.; Reddy, P.V.; Nambigari, N.; Vuruputuri, U.; Singh, S.S.; Satyanarayana, S. Cellular uptake, cytotoxicity, apoptosis, DNA-binding, photocleavage and molecular docking studies of ruthenium (II) polypyridyl complexes. J. Photochem. Photobiol. B Biol. 2014, 132, 111-123. [CrossRef] 
58. Muanza, D.; Kim, B.; Euler, K.; Williams, L. Antibacterial and antifungal activities of nine medicinal plants from Zaire. Pharm. Biol. 1994, 32, 337-345. [CrossRef]

59. Pezzuto, J.; Che, C.; McPherson, D.; Zhu, P.; Topcu, G.; Erdelmeier, C.; Cordell, G. DNA as an Affinity Probe Useful in the Detection and Isolation of Biologically Active Natural Products. J. Nat. Prod. 1991, 54, 1522-1597. [CrossRef]

60. Skehan, P.; Storeng, R.; Scudiero, D.; Monks, A.; McMahon, J.; Vistica, D.; Warren, J.T.; Bokesch, H.; Kenney, S.; Boyd, M.R. New Colorimetric Cytotoxicity Assay for Anticancer-Drug Screening. J. Nat. Cancer Inst. 1990, 82, 1107-1112. [CrossRef]

(c)

(C) 2020 by the authors. Licensee MDPI, Basel, Switzerland. This article is an open access article distributed under the terms and conditions of the Creative Commons Attribution (CC BY) license (http://creativecommons.org/licenses/by/4.0/). 